\title{
Literature, Global Terrorism, Politics and Media Literacy in Africa
}

\author{
Azeez Akinwumi Sesan \\ Al-Hikmah University, Kwara State, Nigeria
}

\section{Introduction}

Three factors, namely slavery, Christian evangelization and colonialism have impacted greatly on the growth and development of African Continent. These three factors brought with them alien civilizations that Africa and Africans at the inception could not easily appropriate into their cultural systems. This marks the very beginning of socio-political and economic problems of Africa.

In the coastal parts of Africa, there were robust commercial activities between Africans and Arabs. These commercial activities were aided by Sahara movement; hence, the trade was named Trans- Sahara. Later some European traders that have their countries shared borders with Africa began commercial activities with Africans on the coast. These European traders could not get to the African hinterland until quinine was discovered to cure the acute malaria fever. The activities of these European traders were further aided by explorations of the African hinterland. Of particular interest to us, in this paper, is the trade activities in slaves. The reason is that slave trade occasioned forced migration of Africans from their continent to Europe and America to work on sugarcane, tobacco and cotton plantations in dehumanized conditions: the mouths of these slaves were padlocked; their legs were chained and their women were raped. These African slaves, consequently, became alienated and exile from their mainstream African culture by the dominant culture of Europe and America.

To satisfy their inquisitiveness about the existence of humans in other parts of the world, particularly in Africa and some yet to be known places in Asian continent, European explorers began the unending journey towards the hinterland of these places. Some of them died on the journey while few survived and lived with people of the hinterland. These explorations and the presence of European traders in 
Africa encouraged Christian Evangelization as these explorers and traders came along with their Bibles.

The stage for colonial engagement of Africa by Europe was set at the Berlin Conference of 1884 when African countries were partitioned for political and economic reasons. In this instance, there was migration of the whites from their home countries to the black colonies. Unlike the forced migration of the blacks in the slave trade era, the migration of the whites was voluntary. The truth of the matter is that the minority white settlers that came to Africa to implement and sustain the colonial agenda of the home government maintained the dominant paradigm through economic, political and military might. During colonialism, there was deprivation of basic social and economic resources for the blacks and underutilization of the black potentials in productive economic activities and public administration. The colonial society had a sort of bipolarity of exotic other for the colonizer and the demonic other for the colonized.

Colonial experience of Africa had ambivalent impact on the socio-political, economic and continental development in the areas of regional integration, the continental challenges of neo-colonialism and mutual mistrust among the different ethnic groups that constitute African polity and politics. The colonial master achieved his colonial agenda and succeeded in the colonial administration by using different administrative antics and pranks on the colonial people (the elites and the masses). To enjoy prolonged dominance in African polity, the colonial government used mainly a divide-and-rule system to create a chasm between the elites and the masses. A few selected Africans were made to enjoy the joys of colonialism at the detriment of the majority. This deformed colonial politics slows the decolonization process in Africa.. The few opportunistic Africans lived in affluence and arrogated powers to themselves with impunity. The angst of nationalists and social critics against the divide-and-rule system and the servant-king syndrome has been expressed in the poetry of R.E.G. Armattoe

Leave them alone,

Leave them to be

Men lost to shame,

To honour lost!

Servant kinglets,

Riding to war

Against their own,

Watched by their foes 
Who urge them on,

And laugh at them!

Leave them alone,

Men lost to shame,

To honour lost. ( West African Verse, 12)

During colonialism, Africans were the machineries of oppression and injustice against their fellow Africans. The implication of this situation is that the seeds of inequity, injustice, favouritism and uncivilized behavior were planted among Africans for the selfish socio-political and economic reasons of the colonial government. We are not oblivious of the fact that colonialism assisted in the development of infrastructural facilities and social amenities in Africa. Africa is still under the weight of foreign debt, foreign military assistance during internal strife, grants and aids, economic bailout and questionable foreign diplomacy.

\section{Literature and African Experience}

Literature, in Africa, is the encyclopaedia of the collective African cultural, social, economic, sociological and political experiences of the continent. African writers are therefore expected to record and reflect these collective experiences in their literary texts. Going this position, it is therefore said that the attention of literary writers in Africa should therefore be shifted from colonial problems to the postcolonial realities of questionable national and foreign diplomacy that degenerated into civil war, political dissent, local terrorism and at large global terrorism. For instance, Wole Soyinka, in A Dance of the Forest (1963), has foreshadowed the problems confronting Nigerian nationality through the symbolic character of the half-child. With the symbolic characterization of the half-child in the "ampe" game, Soyinka foretells that the future of Nigeria is not yet certain in the hands of the power -grabbers that toss the Country around for their selfish motive. The problem is peculiar to nearly all third world countries including Africa.

Even after independence, the marginal position of Africa in the global politics and economy has not changed. The old colonial imperialism only transformed to neoimperialism under the guise of interdependency of nations and bilateral relationship. Largely, African political economy is externally influenced. Hypocrisy and egocentrism characterize how Europe (Eastern and Western) and America relate with Africa and other third world countries. The scramble for the economic potential of Africa still persists among the European powers and with no 
exception of America as demonstrated in the Afro-European and Afro-American economic relationship: Africa provides market for the majority of American and European goods. For this reason, these world super powers do ensure the enthronement of their stooge as the African leader. Many coups and internal strives in Africa have been fully financed and sponsored by Europe and America. Wole Soyinka in A Play of Giants (2006) laments about the European and American questionable interest in African politics and polity.

BATEY. (Studies them both for a while). Isn't this interesting? You sustain this man in power for years with the most sophisticated weaponry. You train his secret service and condone the so-called acts of suppression against his own people. Yet in your heart of hearts, you despise him.

$2^{\mathrm{ND}}$ RUSSIAN. Yes. A common butcher. We knew him. We had close studies of him sent regularly by our men, not just Western reports. But in any case, we did not create him. The British did. They sustained him in power, backed by the Americans. Then they disagreed. The pupil had more than mastered the game of his masters. So we stepped in to fill the vacuum. I admitted to you Mr. Professor, we are Pragmatists. Our policy is that part of the continent required his retention in power. But you sir, what about you?

(A Play of Giants, 55)

The above-mentioned situation shows the hypocrisy of international politics. The super powers enthrone their favourites and stooges in power in the developing and less-developed nation states when the going is good but when there is misunderstanding between these superpowers and their stooges, these super powers dethrone their erstwhile favourites and stooges through civil unrest, demonstrations and riots, coups and counter coups. It is our opinion that Africa and Arabian Peninsula have been worst hit and this has culminated in the phenomenal Arab spring and genocidal war under the pretence of religion, ethnicity and national interest.

In Bode Sowande's Long Story, the ambivalent roles of America in the June 12, 1993 post- electoral crises in Nigeria were presented. The playwright is of the opinion that America did not demonstrate a true sense of justice, equity and probity in the June 12,1993 post election crises. This opinion is demonstrated in the dialogue of HIS EXCEL as shown in the excerpt below: 
HIS EXCEL: That is what I like the Americans for No nation understands money better than America. I tell them, have our crude oil at hundred per cent discount for three months and take off your economic sanctions, let me sort Abiola out my own way with our home -grown democracy. (38)

The above-quoted dialogue of HIS EXCEL in the play, Long Story shows that the motive for economic gain by interfering in the internal political crises of June 12, 1993 post-election crises.

In the genre of poetry, African writers have also examined the impact of slave trade, colonialism and globalization on the sociology of African continent. For instance, Dasylva (2006) has queried the episteme surrounding colonialism, slave trade, Berlin conference and globalization in his volume of poetry Songs of Odamolugbe. He writes:

My sweats, my tears; their milk and tea, my starved soul; their tarred roads, the bitter pain of my lacerated back had fatalized their sugar-canes, the looted mines of aukar and kimbali had beatified their gilded cities, ... their globalized slave trade! every once of my ivory, my diamond, my gold, my oil, ... their abattoir! - $\quad$ all ferried on my pool of blood to their global market fuelling their chariots of fire riding rude on the tarmac of my tethered soul, ... their globalized economy! at the Berlin global conference they scavenged my flesh, ravaged my land, buried my bones in a borrowed tomb of modernist cultures and bastard parents ( 82-3) 
The above-quoted lines of poems show the history and sociology of African politics in relation to Afro-European relationship.

\section{Media and Media Literacy}

Media play significant role in the design, manipulation and sustenance of international diplomacy and body politics. Media have no single definition but what is certain is that the different forms of media-oral, print, electronic, digital and social/virtual media have come to influence our lives and the understanding of the world around us. In the opinion of this paper, media can be described as the means and/or channels through which information and/or news reach individuals that constitute the local, national, regional, continental and/or international audience. Media audience are dispersed, varied and multi- dimensional. Thus, there are expected multifarious and multiple interpretations of media content.

The proliferation of media plays an ambivalent role in global politics, sociopolitical insurgencies and conflict resolution/management. In recent times, media have become political tools of the dominant paradigm in the national, continental and international politics. In Africa and nearly most other third world countries, national governments use the potential of media information and language to manipulate the masses and influence public opinion. Srampickal and Joseph (2002:88-9) refer to this phenomenon as media domination. In their opinion, media domination occurs when the dominant paradigm ( the individual or the group that wields more economic and political powers more than the other individual or group) has the burning passion to maintain and retain the status quo. They write:

No one in a top position ever wants to lose that post. A person, who has tasted power once, has a tendency to cling on to it. Politicians thus become partners in the power game attempting to dominate the media while they are in power. The media are thus used to maintain the status quo. The media can never challenge the establishment. But, with media power, all those who have vested interests in its control, make the ordinary citizen a mere puppet. It is tragic that people often do not even realize that they are being used as pawns in this game of media domination.

To maintain the status quo in the Afro-European and Afro-American relationship, the power blocs of the world (America, Eastern and Western Europe) use media such as BBC World News Channel, Voice of America an CCTV Channels to manipulate and control world politics. 
The global media stations engage in cold war through their subjective reporting. Subjective reporting is selective in its content and media coverage for some diplomatic and political motive. What constitutes news items from the subjective reporting perspective is relative and conditional. Different variables: social, sociological, economic and diplomatic may account for subjective reporting in the global media practices. Fowler (1991:20), by using the genres of newspaper, is of the opinion that:

What is overwhelmingly important is the fact that news-paper publication is an industry and a business, with a definite place in the nation's and world's economic affairs. It is to be expected, then that the activities and the output of the press will be partially determined by considerations related to this fact: by the need to make profit, by the economic organization of the industry; by its external relations with other industries, with financial institutions and with official agencies; by conventional journalistic practices; by production schedules; by relations with labour. All these commercial and industrial structures and relationships are bound to have effect on what is published as news, and how it is presented.

From the viewpoint of Fowler, subjective reporting is unavoidable in human and diplomatic relationship based on the primary factor of power relation between the dominant and the dominated paradigm ( the individual or the group that is less favoured in the order of things). Each group in the social matrix will present issues and cases in the manner that will support their claims and aspirations. When all the possible factors that go into the process of news making are considered, it will become apparent why it is unrealistic to expect objectivity in reporting (Dare, 2004:97). For instance in the Libyan crises that led to the death of Muammar Gaddafi, the parties involved manipulated media to their respective advantage. The European powers used media to justify their interference in Libyan politics and the eventual dethronement of Gaddafi as given in one of the BBC News Bulletin:

Not only was the foreign ministry surrounded, but the interior ministry was ransacked by gunmen demanding salaries, there was a scuffle at the TV station building between gunmen and employees, which a manager said briefly brought work to a halt.

The scenario presented in the above-cited news bulletin is not absolutely objective in the justification for the involvement of America and Europe in the internal politics of Libya. Some section of Libya, as at the time, still wanted Gaddafi to 
continue in power because of the social welfare scheme he put in place for the Libyans. In Nigeria, Boko-Haram insurgency has been characterised by series of subjective media reporting in the print media and the electronic media. For instance, conflicting reports have been given about the cause and the course of this insurgency. For instance, in one of the media reports on the activities of Boko Haram in Nigeria, it was said that the Boko-Haram militants have stopped the series of killings in the Northern part of the country. This report is contrary to the real situation. This subjective media report is countered by the President of the Christian Association of Nigeria (CAN), Pastor Ayo Oritsejafor. In the Sunday Punch of July 14, 2013:3, Oritsejafor said:

' Even if one person says " I want peace and I drop my weapons. I will ask, ' which Boko Haram?' We have seen situations in the past, where they told us that some people wanted truce and the next day we saw people being killed".

The statement of Oritsejafor is an indication that the media reports on the activities of Boko Haram activities in Nigeria are characterized by subjective reporting owing to the variables of politics, religion and ethnicity. In the true sense, there are two factions of Boko Haram militants: The Shekau group and the Ansaru group. Each group also adopts different forms of media publicity for their activities.

The practice of subjective reporting in local and global media engagements makes media literacy inevitable. The phenomenon of media literacy is multifocal and multidimensional as it addresses the issues of the media content, producers, consumers and media effects on the psycho-social behaviour in the social matrix. In the discourse of media literacy, there is a concentric relationship among the media contents, media consumers/audience and the media effect. The media effect can sustain and/or breach human relations. In the opinion of Hybels and Wearer II (2001:603), media literacy is "the ability to access, analyze, evaluate, and communicate information in all its forms -both print and non-print". This view points to the fact that media practitioners and consumers should be critical of the media contents. There are four categories of individuals that are concerned with media literacy for global peace: (i) The owner of the media organization; (ii) The government and / or its designated agencies; (iii) The media practitioners; and (iv)The media audience. Implicitly or explicitly, all these four are stakeholders in the design, determination and dissemination of the media contents. 
Media ethics may be breached if there is fusion of responsibilities. This breach may be in the form of subjective reporting, particularly in a situation where the government owns the media outfit. It is not very uncommon to see government owned media houses on the local and global media scenes. The outcome of this is double standard that affects the quality and effectiveness of the media contents. In this situation, media become political tools for the manipulation of public opinion. To sustain global peace and media ethics, the managers of the government-owned media should heed the advice of Bojuwade (1991:4) according to which:

The ideal press is the one that ethically takes care of that battered but unbowed baneful dogma: He who pays the piper dictates the tune, but he doesn't blow the pipe. The payer does it only for a specific music. And the way to blow the pipe is within the professional wizardry of the journalist. He needs to function within his own ethical initiative in order to supply the music without a discordant note.

The situation presented above provides a model for the operation of governmentownde media house.

Realizing the dynamics of media coverage and contents, we acknowledge the relevance of media literacy in information management. The primary goal of media literacy is to ensure information management for sustainable socio-human relationship at the micro and the macro levels.

The complexity and dynamism of international politics and diplomatic relationship make reliance on global media coverage necessary and unavoidable. Europe, America and Asia rely on the potential of the media to maintain and /or sustain their dominant status in the world politics. BBC, VOA and CNN are Pro-America and Pro-Europe to sustain the assumed dominant paradigm of those two continents. In recent years, there have been counter-hegemonic media coverage and reporting in case of Al-Jazeera and Sahara reporters. This suggests to us that there is an ongoing cold war in the global media industry.

\section{Media Practices and Social Responsibility Theory}

It is no doubt that media have taken a central position in the maintenance and sustenance of global diplomatic relationships. Despite this central position of the media, there is a need for media houses and their practitioners to be socially responsible to all the stakeholders, particularly the consumers of the media contents/messages. 
The etymology of the social Responsibility Media Theory can be traced back to the Hutchins Commission on the Freedom of the Press empowered in the United States of America (1947) to re-examine and re-assess the idea of Press Freedom as contained in the Libertarian/Free Press Theory. Scholars, media and mass communication theorists have identified six basic functions of the press (see Kunczick 1988:48 and McQuail, 1987:116). In their opinions, the six functions of the press are:

(i) to serve the political system by making information, discussion and consideration of public affairs generally accessible;

(ii) to inform the public to enable it to take self-determined action;

(iii) to protect the rights of the individual by acting as watchdog over the government;

(iv) to serve the economic system; for instance by bringing together buyers and sellers through the medium of advertising;

(v) to provide "good" entertainment, whatever "good" may mean in the culture at any point in time;

(vi) To provide financial autonomy in order not to become dependent on special interests and influences.

It is rather quite unfortunate and disheartening that the global media agencies and practitioners have fallen short of the tenets of the social responsibility theory because these tenets are not limited to the American media practices but they are applicable to the media practice across the global world/environment. Media ethics are relatively homogeneous except for some peculiar social milieu across the globe. Related to this observation, Folarin (1998:29) believes that:

Social Responsibility Theory is not a theory for the Western Press alone but for the press in all responsible societies. Quite naturally, the interpretation and the implementation of the theory's tenets will vary in line with any given social milieu.....

Through legislations, decrees and edicts, government across the globe should not militate against effective performance of the media in the gathering and transmission of news bulletin. Contrary to the expectations of the social 
Responsibility Media Theory, media have become the tools for the manipulation of truth and public opinions. Through subjective reporting, global media initiate, instigate, fuel and aggravate crises/conflicts that later degenerate into terrorism (transnational and international). The hyper-presentation of situations of crisis has ruptured the psycho-social behaviour of individual media consumers with ethnopolitical and socio-economic prejudices towards the media contents. For instance, the subjective reporting of NATO military in Israel instigated and fuelled series of violence. Only Mediapart in France and Liberation News in The US reported this news. The media in Germany, UK, Canada, Turkey, Spain and Greece did not cover this incident. This form of media practice is an abuse of Social Responsibility Theory(SRT) and this can jeopardize global peace.

To relatively put transnational and international terrorism under a check, there is an urgent need for the global media agencies and practitioners to adopt some of the tenets of the Social Responsibility Media Theory, particularly in their duty:

(i). to serve the political system by making information, discussion and consideration of public affairs generally accessible;

(ii). to inform the public to enable it to take self-determined action; and

(iii). to protect the rights of the individual by acting as watch dog over government.

By performing the above-mentioned duties diligently, the media agencies and practitioners will address the media needs of the patrons/regulators and the consumers. Eventually, this may enable media practitioners to engage in a balanced presentation of the media content.

\section{(African) Politics, Arab Spring and Terrorism}

African politics and socio-economic activities have become porous since the emergence and popularity of globalized media. Western media subjectively present the internal crisis of Africa and blow it out of proportion to be misrepresented as terrorist activities.

In the opinion of this paper, African politics is attached to the apron strings of the colonial master and western democratic practices. African countries are making efforts to pattern their democratic governance after the Western democracy. 
Oguejiofor (2000:3) is skeptical about the success and survival of democratic governance in Africa. He writes:

The general picture is that democracy in Africa is still very far from being stable. Both in the early days of independence and in the recent wave of democratization, there is hardly any effort to fashion a procedure that will lead to the emergence of a lasting democratic leadership. The signal practice has been to copy the French, British or America models of democracy.

Western models of democracy may not adequately serve the political and administrative needs of Africa because of the continents peculiar problems of ethnic loyalty and mistrust, multiplicity of political organizations and the inordinate ambition of the African political leaders to perpetually remain in power. Sesan ( 2011: 95-6) has identified factors that characterize democratic governance in Africa. He writes:

In Africa, democratic governance has been seen as a dynasty reign patterned after filial relationship, political affiliations, ethnic backgrounds and tribal interests. All these anti-democratic factors prompt different forms of electoral malpractice (registration of under- age voters, printing of fake ballot papers, snatching of ballot boxes, intimidation of electorates, trigger and violence during elections, annulment/cancellation of election results for selfish political reasons and refusal to vacate office at the declaration of election results) that are observable on the continent.

All these deformed electoral practices as identified above prompt pre-electoral, electoral and post-electoral violent crisis that are subjectively blown out of proportion by the western media through their subjective reporting. In Nigeria, electoral processes are characterized by violence, arson, lawlessness and mindless destruction of lives and properties. In some situations, the incumbent political office holders usually refuse to vacate office, even after a free and fair election. The recurrent political upheavals in most African countries such as Egypt, Libya Nigeria and Cote d'Ivoire show the incompetence and the lack of political will of most African leaders to ensure democratic governance in their respective countries.

The political protests and demonstrations that began on 18 December,2010 in the Arab world have been erroneously termed " the Arab spring" by the Western media. These violent demonstrations and protests can be linked with political reforms such as public dissent against long military administration and dynasty 
reigns. The poor management of the public dissent usually resulted in violent crisis and eventually, in genocidal wars. Among the goals of the so-called Arab Spring are democratic governance, free and fair elections, respect for human rights and regime change as in the case of Tunisia and Libya. In some of these political uprisings, the complicity of the western powers has been observed particularly in the case of Libya when the political leader, Muammar Gaddafi was killed after a civil war with foreign military personnel. The term Arab Spring, therefore, has subjective interpretations.

The poor management of conflicts at micro and macro levels of diplomatic relationship degenerates into the misconceived notion of terrorism. In terms of global politics and diplomatic relationships, it can be said that the objective determination of what constitutes terrorism is not possible. The term terrorism has western etymology. It is a recent phenomenon that finds its entry into political discourses following the September 11, 2001 attack on the United States of America the World Trade Centre in New York City and the Pentagon Building in Washington DC. In the opinion of Marshal (2011:3):

The attack itself attained symbolic stature as an affront to the established global order, a challenge to the world's dominant power, and an announcement that the prevailing US-led global order was not viewed, or valued, equally by all those whose daily lives are increasingly caught in the vortex of Post-Cold War change.

From the aforementioned, it can be said that there is no holistic definition and description of the term terrorism. The term terrorism is relative and conditional as different socio-political and economic variables may account for it. The attack on the World Trade Centre and Pentagon Building was more politically-motivated. It was an attempt to deflate the global ego of the United States of America as the super power of the world. In the opinion of this paper, some sociological and sociopolitical factors that may account for terrorism on the local and global political scenes are:

(i). Civil and political unrest;

(ii). Fear of marginalization;

(iii). The need to usurp or maintain regime;

(iv). High level of corruption and corrupt practices;

(v). High level of insecurity and criminal activities;

(vi). Political and religious intolerance. 
In global politics, the dominant paradigm determines and dictates what constitutes terrorism. What name can be given to the series of wars waged by America against Afghanistan, Libya, Kuwait and Iraq? We are therefore of the opinion that global terrorism begins with a wrong interpretation of the global diplomatic codes of conduct (out of omission or commission). The United States of America and the United Nations fought against armament in Iraq and thus killed so many lives and destroyed many valuable properties. They fought this war with sophisticated weaponry. Thus, terrorism is subjective, relative and conditional. Many Western critics of African internal crises have erroneously termed the Arab Spring as terrorism. The primary concern of Arabic Spring is to put an end to the long years of an individual serving as the president without affecting the global peace. This is the case in Egypt and Libya. When internal crises are not well managed, it may degenerate into internal terrorism as in the case of Boko Haram militancy in Nigeria. Some local media outfits have brought it to the public awareness that some members of the Boko Haram group engage the services of terrorists from the neighbouring African countries.

\section{The Way Forward}

Literary and media practitioners should be committed and pro-active in the subject matter of their art. In the state of anomy where it is not too easy to give objective presentation of what is happening, the literary and media practitioners should embark upon "surreptitious insurrection" to comment on the status quo with realistic adjustment to the characters and setting. The plot must not be altered so that the reality to be projected will not become another story (Sesan, 2009:183). Through innuendoes and metaphors, writers are expected to give realistic portraiture of events that are happening in the society. Through the creative use of language, a writer can his points known without being susceptible to the wrath of anybody.

For simplicity, our suggestions are therefore highlighted below:

i. For sustainable democratic governance in Africa, government should adhere to the tenets of constitutionalism. These tenets propose respect for human rights and dignity, rule of law, probity, accountability, transparency and justice. With this, the masses will have a sense of involvement in the democratic governance and this will reduce the cases of incessant civil strives on the continent. 
ii. There should be a purposeful and goal-directed media literacy campaign for all media content producers and consumers at local and global levels. This will reduce the cases of violent reactions that always follow subjective reporting.

iii. In international relations and global politics, the sovereignty of nations should be respected. This should include non-interference in the internal political and economic arrangements of a nation.

iv. Conflict resolutions should always follow the due process of national and international laws. The conflict on the territorial boundary of Bakasi Peninsular is a good instance here. The case is settled with the machinery of law at the World Court.

v. Media literacy, as well as peace literacy should be in school curricular at all levels. This will increase the level of awareness on media literacy and peace literacy.

\title{
Conclusion
}

This paper has examined the place of literature in the representation of the sociopolitical order. It also examines politics in Africa and the politics of terrorism as it affects the sovereignty of African polity and politics. The paper also explores the role media need to play to ensure global peace and therefore recommends effective media literacy for the media content producers and consumers. This is suggested because individuals, government and countries of the world need information for their sustainability and survival. To achieve certain political and economic ends, this information may be subjective. This view has been expressed by Osundare (2005:52) in his collection of poetry, The Word is an Egg that:

\author{
History stammers \\ through its long tirade... \\ We snored too loudly \\ once upon a night \\ Waking up to a mouth \\ Left ajar \\ Its song yoked off \\ to a mapless voyage \\ Murder tongues gave birth \\ To direlects with pidgin curses...
}


Now new tongues are up up up

On the stamp of a millennial silence

Never again will our story go

without a proper telling

\section{References and Notes:}

Armattoe, R.E.G. (2006) "Servant-Kings", in Nwoga, D.I. (ed.) West African Verse. London: Longman.

Bojuwade, D. (1991) The Press and the Public Policy: A Guide to Information Managers. Ibadan: University Press Plc.

Dasylva, A. (2006) Songs of Odamolugbe. Ibadan: Kraftgriots.

Dare, A.S. (2004)" In Defence of Subjective Reporting: A Linguistic Perspectives," in Ibadan Journal of Humanistic Studies, nos. 13\&14; 92-108.

Fowler, R. (1991) Language in the News: Discourse and Ideology in the Press. London and New York: Routledge.

Folarin, B. (1998) Theories of Mass Communication: An Introductory Text. Ibadan: Stirling- Horden Publishers.

Hybel, S. and Weaver II, R.L. (2001) Communicating Effectively. Boston: McGraw-Hill Higher Education.

Kunczick, M. (1988) Concepts of Journalism: North and South. Bonn: Friedrick-Ebertsifting.

Marshall, M.G. (2002) Global Terrorism: An Overview and Analysis. Centre for Systematic Peace, Occasional Paper Series, No 3; 48 pp.

McQuail, D. (1983) Mass Communication Theory: An Introduction. London: SAGE Publications.

Oguejiofor, O. (2000) "In search of Democratic Ideal," in Current ViewPoint: A Review of Culture and Society, Vol. 2, Nos. $1 \& 2$.

Osundare, N. (2005) The Word is an Egg. Ibadan: Kraftgriots

Sesan, A.A (2011) Literacy Perspective on History and Democratic Governance in Africa, in CIRSD: International Journal of Humanities; vol. 3, No =. 2, 88-99.

Sesan, A.A (2009) "Artists, Society and Human Capital Development: The Nigerian Example" in Nkechi, M. Christopher (ed.) Voices from Africa on Literacy for the Attainment of Sustainable Development. Newark (USA). IRA and IDAC.

Sowande, B. (2010) Long Story. Ibadan: Bookbuilders

Soyinka, W. (2006) A play of Giants. Ibadan: Spectrum Books.

Soyinka, W. (1963) A Dance of the Forest. London and New York: Oxford University Press.

Srampickal, J. and Joseph L. (2002) A Text for Media Education. Munbai ( India): Better Yourself Books. 


\title{
Summary
}

\section{Literature, Global Terrorism, Politics and Media Literacy in Africa}

\author{
Azeez Akinwumi Sesan \\ Al-Hikmah University, Kwara State, Nigeria
}

Three factors, specifically, slavery, Proselytization and Colonialism have influenced the history and politics of Africa. The tripartite relationship established among the three factors influences the historical development of African politics. Difference in worldview between the West and third world countries has increased the phenomenon of global terrorism. The paper examines how literary texts in Africa and by Africans have recorded and responded to the political history of the continent in relation with global democratic governance. African writers are therefore expected to project post colonial realities of global terrorism within the gamut of literature. On global terrorism, the paper raises the following questions: What constitutes terrorism and what is global terrorism in relation with media literacy? What are the strategies that can be put in place to check the menace of global terrorism? Terrorism is bifurcated into intra-continental and inter-continental types/forms with their peculiar implication for socio-political development in Africa. African writers should stop over-flogging colonial possession of Africa. They should rather focus on the social, national and continental history of Africa for sustainable democratic governance on the continent. The hermeneutics of social and political events as reflected in the African literary texts, African and global media texts shows that African political problems are multidimensional. Our intention in this paper is therefore to discuss Literature and African experience, media and media literacy, media practices and social responsibility theory as well as ( African) politics, Arab Spring and terrorism.

Keywords: Literature; Arab Spring; Media Literacy; Terrorism; Democratic Governance, Global 